\title{
Influence of Acid Activation on Natural Calcium Montmorillonite Clay
}

\author{
Soniya Sharma ${ }^{\S}$, Dr. Geetha Sarasan ${ }^{\S}$ \\ ${ }^{\S}$ Department of Chemistry, Govt.Holkar Science College, Indore-452001, M.P., India
}

\begin{abstract}
Natural clay drags attention because of their wide application, ample availability, lower cost and ease of modification. Acid treatment of raw clay is easiest way to activate clay. Acid activation improves their bleaching action and also enhances their efficiency as adsorbent. In this paper, study is focused on different aspects of acid activation. Changes in structure, chemical and mineralogical composition and surface morphology have been studied using advanced techniques like FTIR, EDAX, XRD and SEM, respectively. Textural characteristics like surface area, pore volume and average pore diameter were also determined using BET method. The results indicate that surface area is increased four times after acid activation and mesoporosity of the sample also increased. It is observed that octahedral cations were more prone to acid attack rather than tetrahedral one. Due to leaching of octahedral cations and interlayer exchangeable cations, changes in chemical composition and modification in structure has occurred as identified by EDX and FTIR. $X R D$ studies of untreated clay confirmed montmorillonite nature of sample. Results further showed the presence of mineral phase other than montmorillonite. For activated clay, XRD results indicate partial degradation of clay structure as a consequence of acid treatment. Surface morphology reveals that surface of clay is getting improved and grains of quartz can be observed after acid activation.
\end{abstract}

Keywords: Clay, montmorillonite, acid-activation, structural modification.

\section{Introduction}

Natural calcium montmorillonite clay finds application in pharmaceutical preparations, oil refining, sugar refining, as catalyst in organic reactions, in polishes, as a filter aid, as a binder for pencil graphite etc. ${ }^{1}$ It shows bleaching action ${ }^{2,3}$ and also can be effectively used as adsorbent for adsorption of harmful substances like dye $^{4,5}$, heavy metal ions ${ }^{6,7}$ from their sources. Its adsorption capacity as adsorbent and bleaching action can be increased manifold if it is activated particularly with acid. Activation of clay using mineral acids like hydrochloric acid or sulphuric acid increases surface area, surface acidity and pore size distribution, thus making activated clay compete against natural clay. Acid activated clays finds use in the basic and applied research laboratories and in industrial production for many applications ${ }^{8,9}$. The aim of this work is to study the effect of acid activation on natural calcium montmorillonite clay and to determine its suitability for industrial purposes. Changes in physical properties, structure, texture, chemical and mineralogical composition of clay were studied to completely analyze the results of acid treatment.

\section{Materials And Method}

The samples of natural and activated clay were procured from local firm of Indore. Natural clay sample was originally collected from Kutch, Gujarat. For preparing activated clay, it was treated with $25 \%$ sulphuric acid. Both the samples were used without any further purification. The chemical composition of natural calcium montmorillonite clay and acid activated clay was determined using JEOL JSM 5600 Scanning Electron Microscope (SEM) attached with Energy Dispersive X-Ray spectrometer (EDX). SEM was also used to determine the surface morphology of samples under study. For determining mineralogical composition, XRD measurements were done using Rigaku Diffractometer with $\mathrm{CuK}_{\alpha}(\lambda 1.54 \AA)$ radiation. The samples were scanned between $2 \theta$ range of $1^{\circ}-65^{\circ}$. The XRD patterns so obtained for both the samples were compared with those of standard clay material by referring PCPDF Win data for indexing the peaks.

FTIR is very prominent tool to detect structural modification in clay after acid treatment. Study of modification in structure is important as it affects surface acidity, textural properties like pore volume, surface area. FTIR spectra of both samples were taken by $\mathrm{KBr}$ pellet technique using Bruker Vertex 70 FTIR spectrometer in the range 4000 to $400 \mathrm{~cm}^{-1}$. Textural characteristics were determined using volumetric gas adsorption method with advanced free space measurement using $\mathrm{N}_{2}, \mathrm{Ar}, \mathrm{CO}_{2}$ and other non-corrosive gases. 


\section{Results And Discussion}

Changes in natural clay after acid activation:

Appearance: Physical properties of natural clay were examined and are presented in Table 1. It is observed that acid treatment of clay affects appearance also. The color of clay changes from brown to grayish white after acid attack as shown in Figure 1.

Table 1: Physical properties of natural clay

\begin{tabular}{|c|c|c|c|c|c|}
\hline Physical Property & Clay color & Solubility in water & Optical property & Lustre & Refractive index \\
\hline Natural Clay & Brown & insoluble & translucent & dull & 1.575 \\
\hline
\end{tabular}

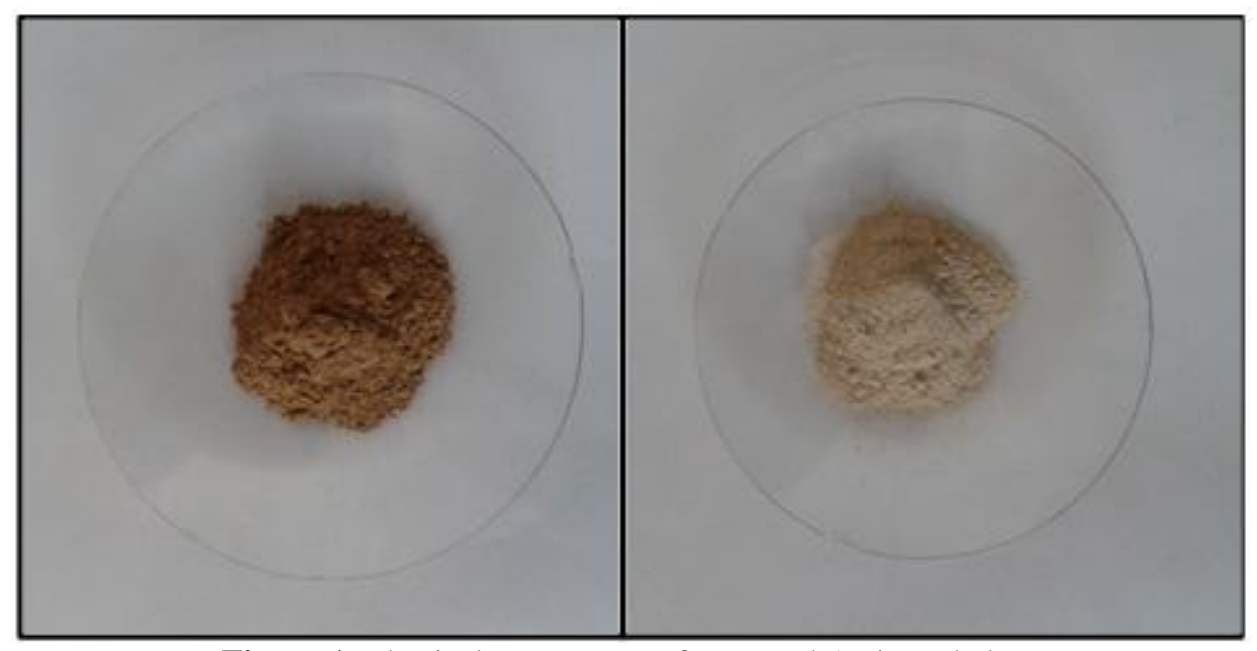

Figure 1: Physical appearance of Raw and Activated clay.

Textural Characteristics: The textural characteristics of both the samples are presented in Table 2. It is observed that surface area of natural clay is enhanced after acid activation as evident from BET specific surface area values. Acid treatment increased specific surface area approximately four times. For natural clay, micropore area contributes $46.77 \%$ and mesopores contributes $53.23 \%$ of the total surface area. This indicates that natural clay is mesoporous. The area of micropores for activated clay contributes only $20.94 \%$ and that of mesopores contributes $79.06 \%$ of the total surface area. This is a clear indication that acid leaching causes empty spaces to grow larger and transformation of micropores into mesopores has occurred ${ }^{10}$. Thus making acid treated clay highly mesoporous. The high mesoporosity of acid activated clay was further confirmed when mesopore volume was compared with the total pore volume. The mesopore volume contributes $89.44 \%$ of the total pore volume. Moreover, the average pore diameter for untreated clay is $6.20 \mathrm{~nm}$ and for treated one is 5.09 $\mathrm{nm}$ shows that the adsorbents are mesoporous (depending upon the pore diameter, adsorbent can be microporous ( pore diameter $<2 \mathrm{~nm}$ ), mesoporous (pore diameter range between $2-50 \mathrm{~nm}$ ) and macroporous ( pore diameter $>50 \mathrm{~nm})^{11}$. It is clear from the above results that acid activation of natural clay decreases microporous structure existing in calcium montmorillonite clay there by increasing the mesoporosity.

Table 2: Textural characteristics of natural and activated clay.

\begin{tabular}{|c|c|c|c|c|c|c|c|}
\hline Adsorbent & $\begin{array}{l}\text { BET specific } \\
\text { surface area }^{a} \\
\quad\left(\mathrm{~m}^{2} \mathrm{~g}^{-1}\right)\end{array}$ & $\begin{array}{c}\text { Mesopore } \\
\text { specific } \\
\text { surface area } \\
\left(\mathrm{m}^{2} \mathrm{~g}^{-1}\right)\end{array}$ & $\begin{array}{c}\text { Micropore } \\
\text { specific } \\
\text { surface area } \\
\left(\mathrm{m}^{2} \mathrm{~g}^{-1}\right)\end{array}$ & $\begin{array}{l}\text { Total pore } \\
\text { volume } \\
\left(\mathrm{cm}^{3} \mathrm{~g}^{-1}\right)\end{array}$ & $\begin{array}{l}\text { Mesopore } \\
\text { Volume } \\
\left(\mathrm{cm}^{3} \mathrm{~g}^{-1}\right)\end{array}$ & $\begin{array}{c}\text { Micropore } \\
\text { Volume } \\
\left(\mathrm{cm}^{3} \mathrm{~g}^{-1}\right)\end{array}$ & $\begin{array}{l}\text { Average } \\
\text { pore } \\
\text { diameter } \\
(\mathrm{nm})\end{array}$ \\
\hline 1.) Natural Clay & 70.65 & 37.61 & 33.04 & 0.1095 & 0.092 & 0.0175 & 6.20 \\
\hline 2.) Activated Clay & 297 & 234.8 & 62.2 & 0.3779 & 0.338 & 0.0399 & 5.09 \\
\hline
\end{tabular}

${ }^{a}$ multipoint BET method

${ }^{\mathrm{b}}$ Obtained from Barrette-Joyner-Hanlenda (BJH) method

${ }^{c}$ Calculated from the amount of $\mathrm{N}_{2}$ adsorbed at $\mathrm{P} / \mathrm{P}_{0}=0.990$

Chemical Composition using EDX: Figure 2 and 3 shows the EDX spectra of both the samples from which elemental composition can be determined. It is observed that both the samples have high $\%$ of silicon, aluminium and oxygen. Other elements like sodium, magnesium, calcium, iron etc. are present in minor quantity. With the help of elemental composition, chemical composition of samples was determined by converting them to oxide $\%$ and is given in Table 3. 


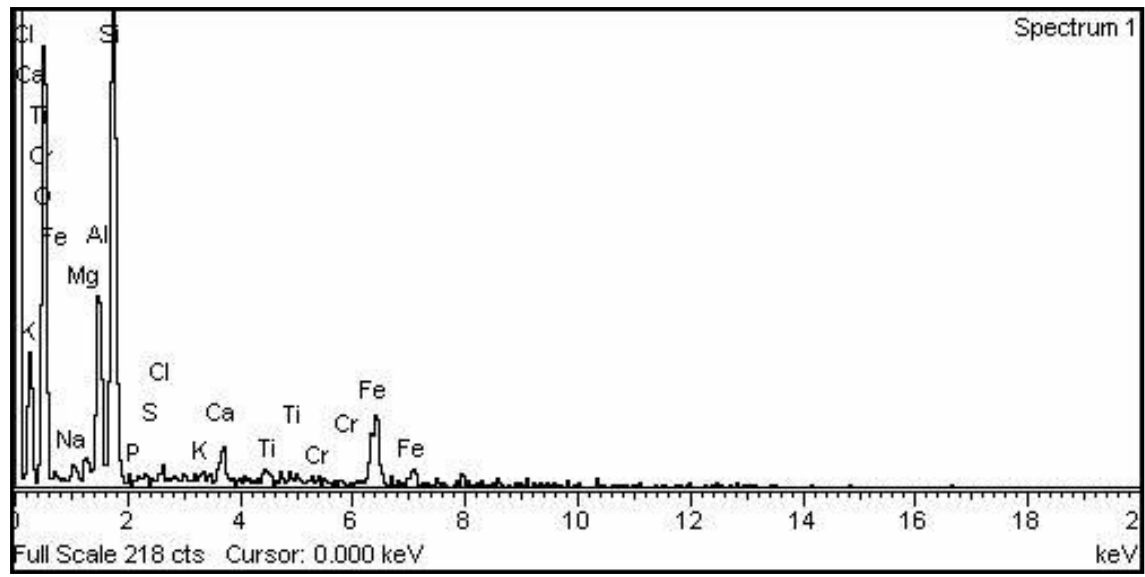

Figure 2: EDX spectra of natural clay.

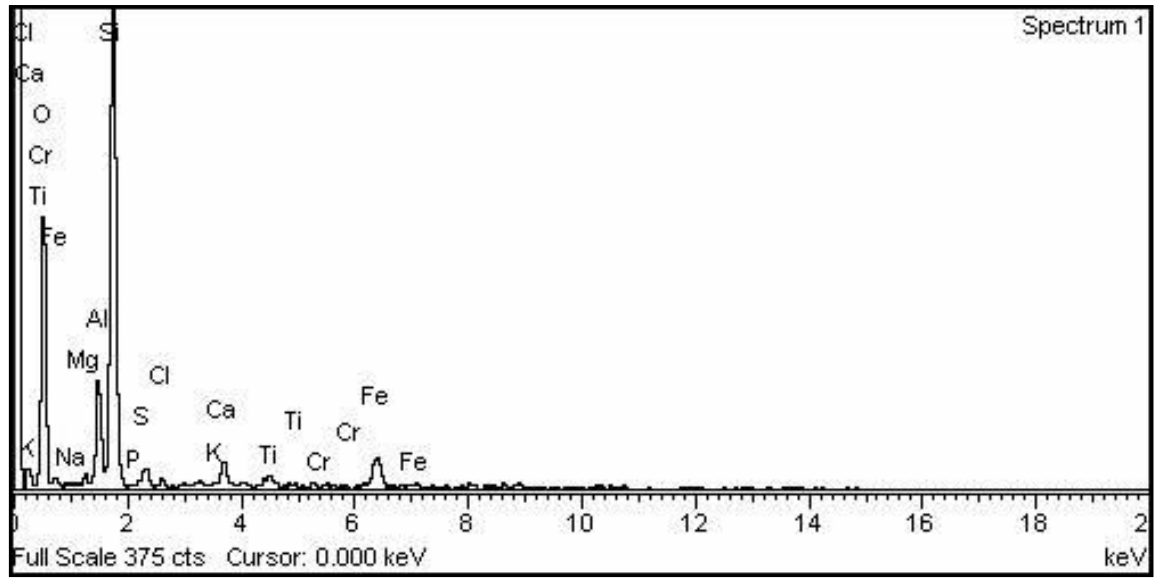

Figure 3: EDX spectra of activated clay.

Table 3: Chemical composition of natural and activated clay.

\begin{tabular}{|c|c|c|}
\hline \multirow{2}{*}{ Oxide } & \multicolumn{2}{|c|}{ Weight \% } \\
\cline { 2 - 3 } & Natural clay & Activated clay \\
\hline $\mathrm{SiO}_{2}$ & 43.19 & 59.83 \\
\hline $\mathrm{Al}_{2} \mathrm{O}_{3}$ & 13.77 & 9.77 \\
\hline $\mathrm{Fe}_{2} \mathrm{O}_{3}$ & 14.18 & 8.48 \\
\hline $\mathrm{CaO}$ & 2.18 & 2.59 \\
\hline $\mathrm{Na}_{2} \mathrm{O}$ & 1.97 & 0.00 \\
\hline $\mathrm{MgO}$ & 1.79 & 0.00 \\
\hline $\mathrm{TiO}_{2}$ & 1.53 & 1.83 \\
\hline $\mathrm{SO}_{3}$ & 0.00 & 2.90 \\
\hline $\mathrm{Cl}^{*}$ & 0.55 & 0.58 \\
\hline $\mathrm{LOI}^{*}$ & 20.29 & 14.02 \\
\hline Total & 100.00 & 100.00 \\
\hline
\end{tabular}

* loss on ignition

From Table 3 it is evident that Silica $\left(\mathrm{SiO}_{2}\right)$, Alumina $\left(\mathrm{Al}_{2} \mathrm{O}_{3}\right)$ and Hematite $\left(\mathrm{Fe}_{2} \mathrm{O}_{3}\right)$ are the major constituents of untreated clay with calcium, sodium, magnesium, titanium oxides as well as chlorine present in minor quantity and are found as impurities. The type of clay is indicated by the ratio of $\mathrm{SiO}_{2} / \mathrm{Al}_{2} \mathrm{O}_{3}$. For our sample, $\mathrm{SiO}_{2} / \mathrm{Al}_{2} \mathrm{O}_{3}$ ratio is 3.14 which indicate the montmorillonite nature of clay ${ }^{12,13}$. This is also confirmed by XRD patterns of this sample. The high \% of silica, alumina and hematite signifies that the clay mineral is montmorillonite. In order to distinguish between sodium and calcium montmorillonite, we calculate the ratio of $\mathrm{Na}_{2} \mathrm{O}$ to $\mathrm{CaO}$. If the above ratio is less than 1 , it suggests absence of swelling in the clay and clay can be classified as calcium montmorillonite ${ }^{14},{ }^{3}$. For our sample, the ratio of $\mathrm{Na}_{2} \mathrm{O}$ to $\mathrm{CaO}$ is 0.90 , therefore it is calcium montmorillonite clay. It is observed that change in chemical composition of calcium montmorillonite clay has occurred after acid activation as evident from Table 3. It can be said that montmorillonite structure is modified by acid treatment. This is again evident from XRD and FTIR analysis. 
Mineralogical composition using XRD:

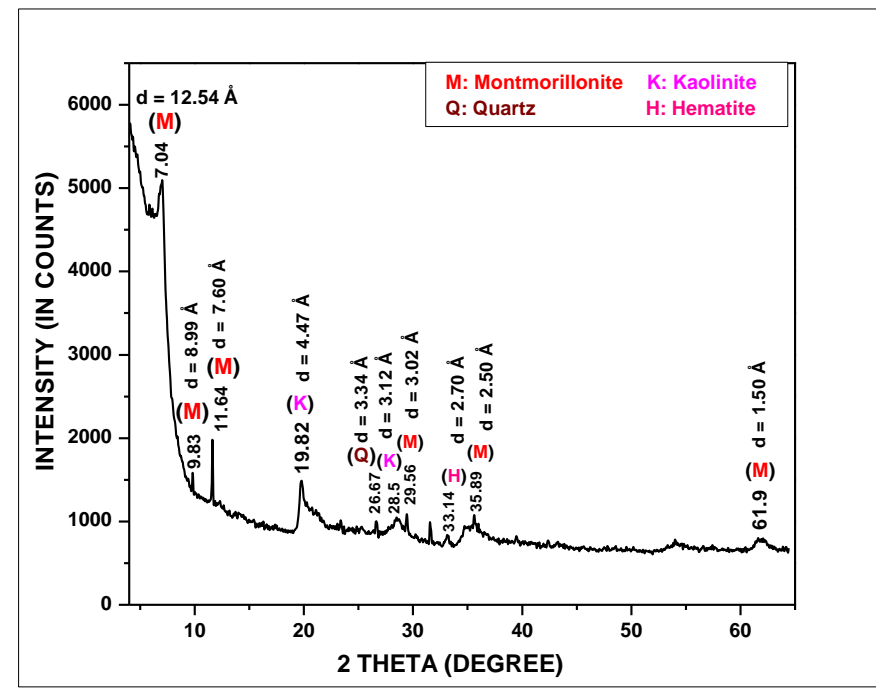

Figure 4: XRD spectra of natural clay.

Figure 4 shows mineralogical composition of untreated clay. It is observed from the XRD pattern of raw clay that it contains montmorillonite, kaolinite, quartz and hematite. The $\mathrm{d}$ values are calculated using Bragg's equation $(n \lambda=2 \mathrm{~d} \sin \theta)$. The $\mathrm{d}_{001}$ basal spacing value for the sample of natural clay is $12.54 \AA$ at 7.04 (20) which correspond to montmorillonite as major component in the sample. When the clay is treated with acid, its crystallinity is decreased. In fact, the strongest line intensity at $7.04(2 \theta)$ completely disappeared (Figure 5) as a result of acid attack. Reduction in intensity of certain peaks shows partial degradation of montmorillonite structure with formation of amorphous phase $\mathrm{e}^{10}$.

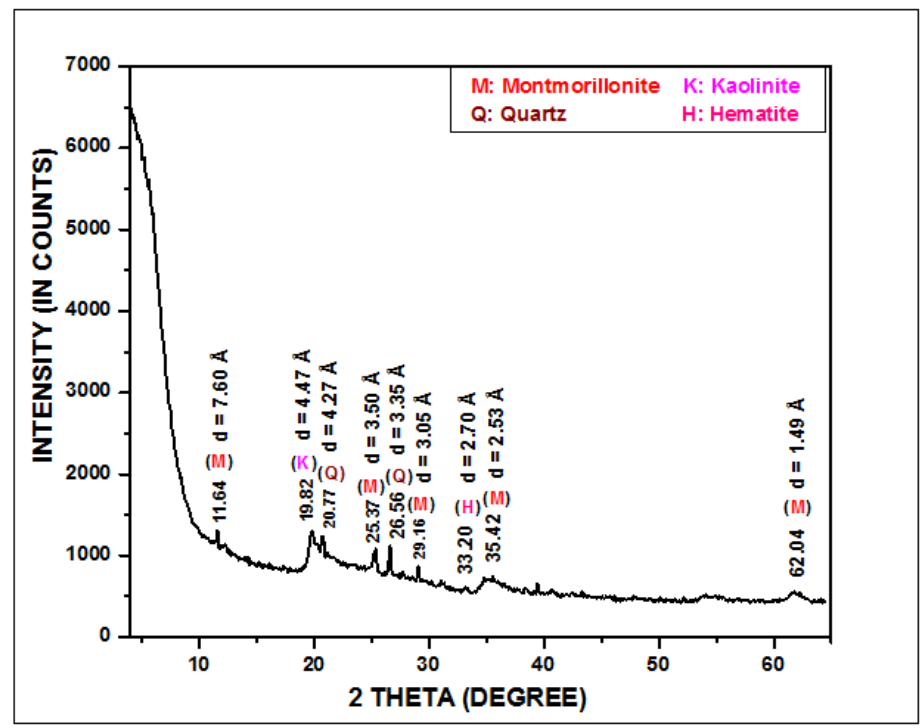

Figure 5: XRD spectra of activated clay.

Structural modification using FTIR: Changes in chemical composition of natural clay after acid treatment as identified using EDX and presence of mineralogical phases other than montmorillonite as recognized by XRD, both can be further confirmed by FTIR technique. Figure 6 shows FTIR spectra of natural and activated clay. Tentatively assigned bands for both the samples are given in Table 4.

Assignment of bands for natural clay: The bands at $3696 \mathrm{~cm}^{-1}, 3620 \mathrm{~cm}^{-1}$ and $3423 \mathrm{~cm}^{-1}$ show the presence of hydroxyl linkage in clay. The former two bands show that the hydroxyl group is coordinated with octahedral cations like $\mathrm{Al}^{3+}$ and band at $3423 \mathrm{~cm}^{-1}$ is for structural hydroxyl group of water. Now band at $1639 \mathrm{~cm}^{-1}$ shows hydration of water. The bands particularly in the region $1600-400 \mathrm{~cm}^{-1}$ helps in detection of surface active groups. A little hump at $1113 \mathrm{~cm}^{-1}$ and intense band at $1029 \mathrm{~cm}^{-1}$ shows Si-O stretching vibrations, out-of-plane 
and in-plane, respectively. The less intense band at $913 \mathrm{~cm}^{-1}$ and inflexion at $875 \mathrm{~cm}^{-1}$ and $836 \mathrm{~cm}^{-1}$ shows bending vibrations of $\mathrm{Al}-\mathrm{Al}-\mathrm{OH}, \mathrm{Al}-\mathrm{Fe}-\mathrm{OH}$ and $\mathrm{Al}-\mathrm{Mg}-\mathrm{OH}$, respectively. Low intensity of these bands shows low content of Fe and $\mathrm{Mg}$ in clay. Pair of bands at $530 \mathrm{~cm}^{-1}$ and $467 \mathrm{~cm}^{-1}$ is due to Al-O-Si and Si-O-Si bending vibrations. Now montmorillonite is dioctahedral clay which is further confirmed by $3620 \mathrm{~cm}^{-1}$ and $913 \mathrm{~cm}^{-1}$ vibrations. ${ }^{15}, 161718,1920$

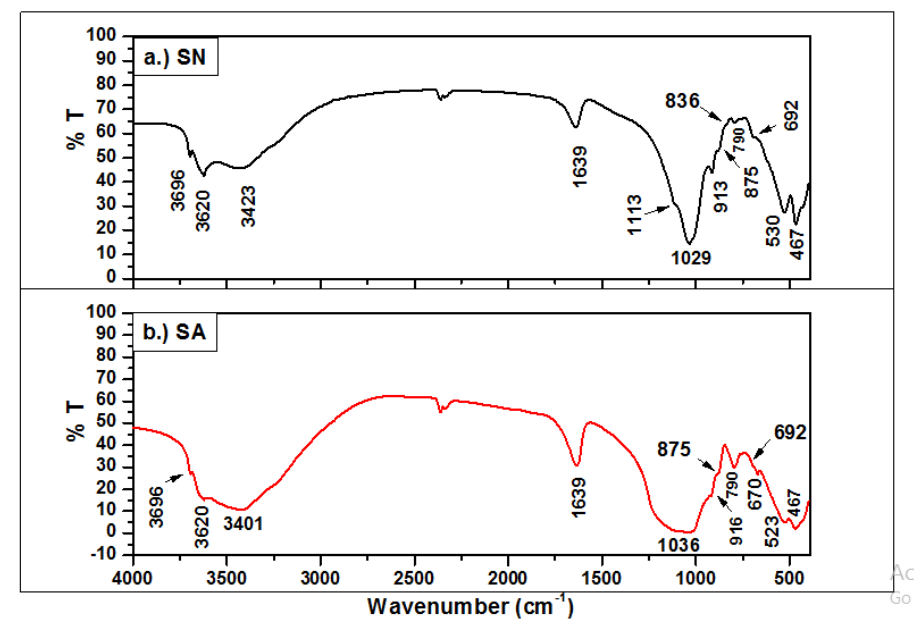

Figure 6: FTIR spectra of a.) Natural clay and b.) Activated clay.

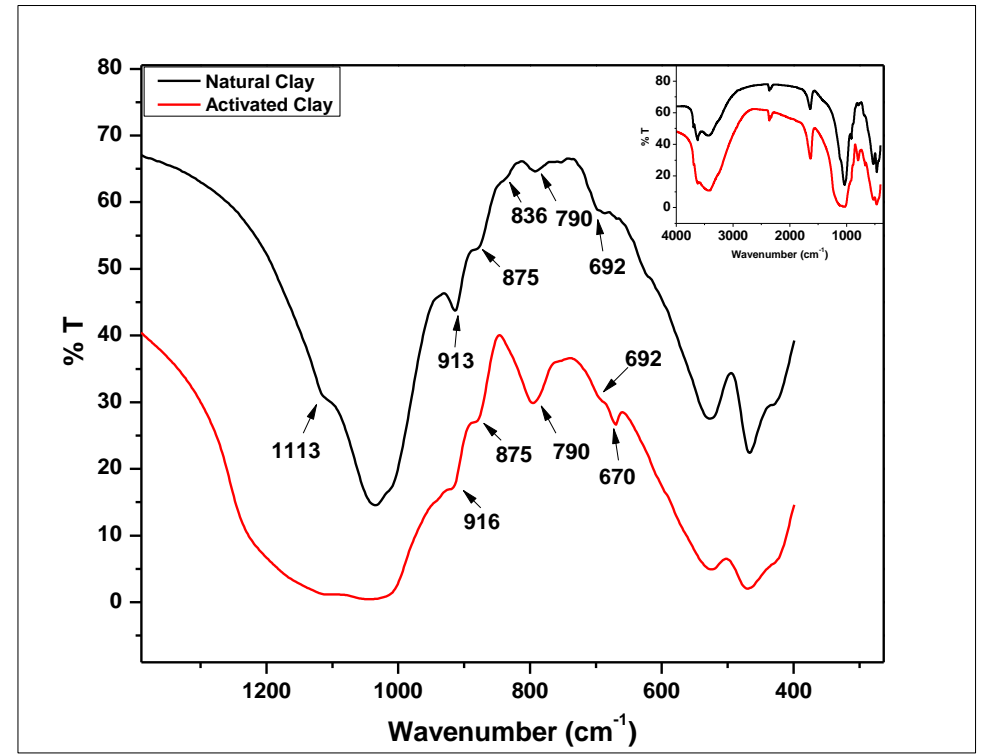

Figure 7: Enlarged view of FTIR spectra of the samples in the range $1400-400 \mathrm{~cm}^{-1}$.

Table 4: Possible IR assignments for natural and activated clay.

\begin{tabular}{|c|c|c|}
\hline \multicolumn{2}{|c|}{ Wavenumber $\left(\mathrm{cm}^{-1}\right)$} & Assignments \\
\hline Natural clay & Acid activated clay & $v-\mathrm{O}-\mathrm{H}$ coordinated with Oh cations \\
\hline $3696 \mathrm{~cm}^{-1}$ & $3696 \mathrm{~cm}^{-1}$ & $v$ Al-O-H \\
\hline $3620 \mathrm{~cm}^{-1}$ & $3620 \mathrm{~cm}^{-1}$ & $v$ H-O-H for structural hydroxyl \\
\hline $3423 \mathrm{~cm}^{-1}$ & $3401 \mathrm{~cm}^{-1}$ & deformation of water \\
\hline $1639 \mathrm{~cm}^{-1}$ & $1639 \mathrm{~cm}^{-1}$ & $v$ - Si-O of quartz, out-of-plane \\
\hline $1113 \mathrm{~cm}^{-1}$ & - & $\delta$ Al-Al-OH \\
\hline $1029 \mathrm{~cm}^{-1}$ & $1036 \mathrm{~cm}^{-1}$ & $\delta$ Al-Fe-OH \\
\hline $913 \mathrm{~cm}^{-1}$ & $916 \mathrm{~cm}^{-1}$ & $\delta$ Al-Mg-OH \\
\hline $875 \mathrm{~cm}^{-1}$ & $875 \mathrm{~cm}^{-1}$ & $v-\mathrm{Si}-\mathrm{O}$ of quartz \\
\hline $836 \mathrm{~cm}^{-1}$ & - & $v-\mathrm{Si}-\mathrm{O}$ of quartz \\
\hline $790 \mathrm{~cm}^{-1}$ & $790 \mathrm{~cm}^{-1}$ & $v-\mathrm{Si}-\mathrm{O}$ \\
\hline $692 \mathrm{~cm}^{-1}$ & $692 \mathrm{~cm}^{-1}$ & $\delta$ Al-O-Si \\
\hline- & $670 \mathrm{~cm}^{-1}$ & $\delta$ Si-O-Si \\
\hline $530 \mathrm{~cm}^{-1}$ & $523 \mathrm{~cm}^{-1}$ & $467 \mathrm{~cm}^{-1}$ \\
\hline $467 \mathrm{~cm}^{-1}$ & & \\
\hline
\end{tabular}


Presence of other mineralogical phase: The bands at $790 \mathrm{~cm}^{-1}, 692 \mathrm{~cm}^{-1}, 530 \mathrm{~cm}^{-1}$ and $467 \mathrm{~cm}^{-1}$ can also be assigned for quartz. Presence of kaolinite is also confirmed by the bands at $3696 \mathrm{~cm}^{-1}$ and $913 \mathrm{~cm}^{-1}$. Vibration at $913 \mathrm{~cm}^{-1}$ can also be assigned for hematite. ${ }^{16}, 17$

Modification in structure due to acid treatment: From Figure 6 b.), it is clear that changes in clay structure has occurred due to acid attack. The decrease in intensities of bands at $3696 \mathrm{~cm}^{-1}$ and $3620 \mathrm{~cm}^{-1}$ shows that octahedral cation $\mathrm{Al}^{3+}$ is removed due to acid attack which results in loss of hydroxyl groups attached with it and water. The band at $3423 \mathrm{~cm}^{-1}$ (Figure 6 a.) is shifted to $3401 \mathrm{~cm}^{-1}$ and becomes broad (Figure $6 \mathrm{~b}$.). Further it is observed that intensity of band at $1639 \mathrm{~cm}^{-1}$ also increases. Change in the environment of tetrahedral ion $\mathrm{Si}^{4+}$ is also identified by the appearance of broad band at $1036 \mathrm{~cm}^{-1}$ which is originally shifted from $1029 \mathrm{~cm}^{-1}$, and disappearance of band at $1113 \mathrm{~cm}^{-1}$. Change in intensity of bands at $913 \mathrm{~cm}^{-1}, 875 \mathrm{~cm}^{-1}$ and $836 \mathrm{~cm}^{-1}$ show confirm substitution of $\mathrm{Fe}^{2+}$ and $\mathrm{Mg}^{2+}$. It is noteworthy to mention here that the band at $875 \mathrm{~cm}^{-1}$ reduces in intensity and at $836 \mathrm{~cm}^{-1}$ disappeared it means higher leaching of $\mathrm{Mg}^{2+}$ than $\mathrm{Fe}^{2+}$ ion. $\mathrm{Mg}^{2+}$ is more susceptible to acid attack. Increase in intensity of band at $790 \mathrm{~cm}^{-1}$ and appearance of band at $670 \mathrm{~cm}^{-1}$ confirms increase in $\%$ of $\mathrm{SiO}_{2}$ after acid treatment. Tetrahedral $\mathrm{Si}^{4+}$ ions are less prone to acid attack in comparison to octahedral $\mathrm{Al}^{3+}$ ions which are more susceptible. Thus, silica content increases due to leaching of octahedral and interlayer exchangeable cations. To some extent tetrahedral sheet is also affected by acid treatment as evident by shift in position of band at $530 \mathrm{~cm}^{-1}$ to $523 \mathrm{~cm}^{-1}$ and its reduction in intensity. Moreover change in octahedral sheet has also occurred which is evident by reduced intensity of vibration at $467 \mathrm{~cm}^{-1}$.

\section{Surface morphology using SEM:}

Figure 8 shows the SEM images of natural clay as well as the natural clay treated with acid. The surface morphology of natural clay is shown in the left panel of Figure 8 and that of activated clay is shown in the right panel of Figure 8. From the left panel of Figure 8, it is observed that the particles in natural clay are sub-angular in shape. Acid activation enhances the surface area of the clay. From the SEM image of activated clay, it is evident that due to acid attack, surface is getting improved and smooth grains of quartz are seen on the particles.

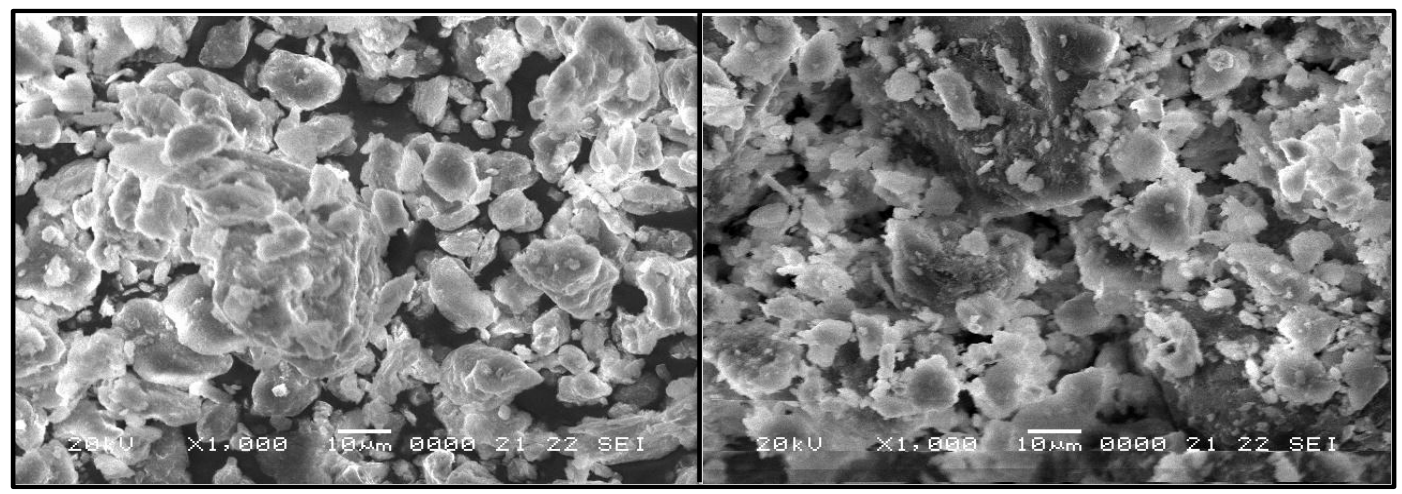

Figure 8: SEM images (surface morphology) of natural and activated clay.

\section{Conclusion}

From the above results and discussion, various aspects of acid activation of calcium montmorillonite clay can be concluded as follows:

1. Acid activation affects physical appearance of clay which is observed by change in color from brown to grayish white.

2. There was fourfold increase in the specific surface area of activated clay when compared with raw clay.

3. Acid treatment decreases the microporous structure of calcium montmorillonite clay, thereby increasing the mesoporosity.

4. The $\mathrm{Si}^{4+}$ ions situated at tetrahedral sites of smectite clay were resistant to acid attack due to leaching of interlayer exchangeable cations $\left(\mathrm{Na}^{+} / \mathrm{Ca}^{2+}\right)$ and also due to depletion of cations $\left(\mathrm{Fe}^{2+} / \mathrm{Al}^{3+} / \mathrm{Mg}^{2+}\right)$ at octahedral sites. Thus, change in chemical composition with a marked increase in $\%$ of $\mathrm{SiO}_{2}$ and decrease in $\%$ of $\mathrm{Al}_{2} \mathrm{O}_{3}$ and $\mathrm{Fe}_{2} \mathrm{O}_{3}$ has occurred.

5. FTIR studies further confirmed the change in chemical composition due to acid attack and presence of other minerals in clay.

6. XRD of natural clay showed its montmorillonite nature with characteristic $d_{001}$ value $12.54 \AA$ at $7.04(2 \theta)$. Acid treatment caused partial degradation of montmorillonite structure of clay.

7. Study of surface morphology using SEM revealed that the surface of the clay is getting improved and smooth grains of quartz are seen on it after treatment with acid. 


\section{Acknowledgements}

The authors are grateful to UGC-DAE Consortium for Scientific Research, Indore for conducting XRD, SEMEDS and FTIR measurements of our samples.

\section{References}

[1] Hartwell, J. M. The Diverse Uses of Montmorillonite. Clay Miner. 6, 111-118 (1965).

[2] Falaras, P., Lezou, F., Seiragakis, G. \& Petrakis, D. Bleaching properties of alumina-pillared acid-activated montmorillonite. Clays Clay Miner. 48, 549-556 (2000).

[3] Usman, M. A., Ekwueme, V. I., Alaje, T O., A. \& Mohammed, A. O. Characterization , Acid Activation , and Bleaching Performance of Ibeshe Clay, Lagos, Nigeria. Int. Sch. Res. Netw. 2012, 1-6 (2012).

[4] Yavuz, Ö. \& Aydin, A. H. Removal of Direct Dyes from Aqueous Solution Using Various Adsorbents. Polish J. Environ. Stud. 15, 155-161 (2006).

[5] Tahir, H., Hammed, U., Sultan, M. \& Jahanzeb, Q. Batch adsorption technique for the removal of malachite green and fast green dyes by using montmorillonite clay as adsorbent. African J. Biotechnol. 9, 8206-8214 (2010).

[6] Geetha, K. S. \& Belagali, S. L. Removal of Heavy Metals and Dyes Using Low Cost Adsorbents from Aqueous Medium- , A Review. IOSR J. Environ. Sci. Toxicol. FoodTechnology 4, 56-68 (2013).

[7] Bhattacharyya, K. G. \& Gupta, S. Sen. Adsorption of Fe(III) from water by natural and acid activated clays: Studies on equilibrium isotherm, kinetics and thermodynamics of interactions. Adsorption 12, 185-204 (2006).

[8] Komadel, P. \& Madejová, J. Developments in Clay Science Chapter 7 . 1 Acid Activation of Clay Minerals. Handbook of Clay Science 1, (2006).

[9] Makhoukhi, B., Didi, M. A., Villemin, D. \& Azzouz, A. Acid activation of Bentonite for use as a vegetable oil bleaching agent. Grasas y Aceites 60, 343-349 (2009).

[10] Motlagh, K., Youzbashi, A. A. \& Rigi, Z. A. Effect of acid activation on structural and bleaching properties of a bentonite. Iran. J. Mater. Sci. Eng. 8, 50-56 (2011).

[11] Al-Degs, Y. S., El-Barghouthi, M. I., El-Sheikh, A. H. \& Walker, G. M. Effect of solution pH, ionic strength, and temperature on adsorption behavior of reactive dyes on activated carbon. Dye. Pigment. 1-8 (2007). doi:10.1016/j.dyepig.2007.03.001

[12] Karima, B., Mossab, B. L. \& A-hassen, M. Removal of Methylene Blue from aqueous solutions using an Acid Activated Algerian Bentonite : Equilibrium and Kinetic Studies. Int. Renew. Energy Congr. 360-367 (2010).

[13] Al-Khatib, L., Fraige, F., Al-Hwaiti, M. \& Al-Khashman, O. Adsorption from aqueous solution onto natural and acid activated bentonite. Am. J. Environ. Sci. 8, 510-522 (2012).

[14] Ujeneza, E., Njenga, H. N., Mbui, D. N. \& Kariuki, D. N. Optimization of Acid Activation Conditions for Athi River Bentonite Clay and Application of the Treated Clay in Palm Oil Bleaching. IOSR J. Appl. Chem. 7, 29-38 (2014).

[15] Joshi, G. V., Kevadiya, B. D., Patel, H. A., Bajaj, H. C. \& Jasra, R. V. Montmorillonite as a drug delivery system: Intercalation and in vitro release of timolol maleate. Int. J. Pharm. 374, 53-57 (2009).

[16] Nayak, P. S. \& Singh, B. K. Instrumental characterization of clay by XRF, XRD and FTIR. Bull. Mater. Sci. 30, 235-238 (2007).

[17] Tyagi, B., Chudasama, C. D. \& Jasra, R. V. Determination of structural modification in acid activated montmorillonite clay by FTIR spectroscopy. Spectrochim. Acta - Part A 64, 273-278 (2006).

[18] Mukasa-Tebandeke, I. Z. et al. The Elemental, Mineralogical, IR, DTA and XRD Analyses Characterized Clays and Clay Minerals of Central and Eastern Uganda. Adv. Mater. Phys. Chem. 5, 67-86 (2015).

[19] Hattab, A. Characterization of Tataouines Raw and Activated Clay. J. Chem. Eng. Process Technol. 4, 1-5 (2013).

[20] Wanyika, H. Instrumental characterization of montmorillonite clays by X-ray fluorescence spectroscopy, fourier transform infrared spectroscopy, x-ray diffraction and uv/visible spectrophotometry. Jomo Kenyatta Univ. Agric. Technol. 17, 224-239 (2016). 